Henryk Sławiński

Uniwersytet Papieski Jana Pawła II w Krakowie

\title{
Przepowiadanie do ludzi w podeszłym wieku
}

Głoszenie słowa Bożego to wydarzenie, w które zaangażowani są: Pan Bóg, głosiciel i słuchacze. Pan Bóg - ponieważ przepowiadanie to głównie Jego dzieło i Jego wola, by plan Boży był głoszony ludziom. Głosiciel, reprezentujący Kościół - ponieważ posługa słowa nie jest prywatnym przedsięwzięciem, ale zadaniem zleconym przez Boga Kościołowi, który posyła głosicieli, kontynuując misję Syna Bożego, który został posłany przez Ojca, o czym sam powiedział: „Jak Ojciec Mnie posłał, tak i Ja was posyłam” (J 20, 21). I wreszcie słuchacze ponieważ przepowiadanie jest wydarzeniem wspólnotowym skierowanym zawsze do określonych adresatów, w trosce o ich dobro - wieczne zbawienie.

To właśnie na słuchaczach skupimy uwagę w poniższym opracowaniu. Najpierw nawiążemy do nurtu „nowej homiletyki”, który rozwinął się w latach siedemdziesiątych $\mathrm{xx}$ wieku, skupiając uwagę na adresatach słowa Bożego, a następnie wyróżnimy w tej grupie słuchaczy najstarszych i omówimy specyfikę przepowiadania do nich. Refleksja naukowa na ten temat jest o tyle uzasadniona, że brakuje w polskiej homiletyce publikacji na temat przepowiadania do starszych. Może się to wydawać nieco dziwne, ale faktem jest, iż w powojennej Bibliografii homiletycznej, obejmującej lata 1945-2005, nie ma żadnej publikacji na temat przepowiadania do starszych czy do osób w podeszłym wieku, jakkolwiek są liczne opracowania na temat przepowiadania do dzieci czy młodzieży'. Jedyną publikacją uzupełniającą tę lukę jest artykuł Adama Kalbarczyka opublikowany w 2015 roku na łamach kwartalnika „Polonia Sacra”2. Jego

\footnotetext{
1 Polska bibliografia homiletyczna 1945-2005, oprac. W. Przyczyna, L. Szewczyk, Kraków 2007.

2 A. Kalbarczyk, „Nie odtrącaj mnie $w$ starości”. O potrzebie profilowanego przepowiadania dla seniorów, „Polonia Sacra” 38 (2015) nr 1, s. 115-130.
} 
autor przypomina, za Antonim Lewkiem³ ${ }^{3}$ że przepowiadanie słowa Bożego, chcąc dotrzeć $\mathrm{z}$ Ewangelią do adresatów, musi dostrzegać i uwzględniać różnice między nimi spowodowane wiekiem, stanem, płcią czy zawodem. W związku z tym Kalbarczyk upomniał się o profilowane przepowiadanie do ludzi starych, przede wszystkim $\mathrm{w}$ duszpasterstwie specjalnym ${ }^{4}$. Zabrakło jednak w tym opracowaniu próby opisu, kim są ludzie starsi $i^{5}$ Zostanie ona podjęta poniżej. Niniejsze opracowanie dopełnia refleksję nad starszymi słuchaczami słowa Bożego. Jego celem jest uwrażliwienie homiletów i głosicieli słowa Bożego na specyfikę tej grupy adresatów. Toteż najpierw zostanie omówione miejsce ludzi starszych w życiu parafialnym, a następnie ta grupa ludzi zostanie opisana jako audytorium kościelnego przepowiadania. W konsekwencji zaś omówione będą najważniejsze kwestie egzystencjalne, które dotyczą tej grupy słuchaczy, sposób i okoliczności przepowiadania do nich oraz rola głosiciela wobec takiego audytorium.

\section{Ludzie starsi - określenie grupy adresatów}

Określenie, kto zalicza się do ludzi starszych, nie jest łatwe do sprecyzowania. Można jednak tę grupę opisać. Sugestii do określenia, co oznacza termin „starsi”, dostarcza tekst objawiony, w którym znajdujemy znaną wypowiedź psalmisty:

Miarą naszych lat jest lat siedemdziesiąt

lub, gdy jesteśmy mocni, osiemdziesiąt;

a większość $\mathrm{z}$ nich to trud i marność:

bo szybko mijają, my zaś odlatujemy

Ps 90 [89], 10

Komentując te biblijne słowa, Jan Paweł II zauważył, że „w epoce, gdy Psalmista pisał te słowa, siedemdziesiąt lat uważano za wiek bardzo podeszły i niewielu przekraczało tę granicę; dzisiaj, dzięki postępom medycyny oraz lepszym warunkom społecznym i ekonomicznym, w wielu regionach świata

3 Zob. A. Lewek, Współczesna odnowa kaznodziejstwa. Zarys homiletyki ogólnej, z. 2, Warszawa 1980, s. 106.

4 A. Kalbarczyk, „Nie odtrącaj mnie w starości”..., dz. cyt., s. 117-118.

5 Autor stwierdził jedynie bardzo ogólnie, że ma na myśli „ludzi w wieku senioralnym, na tyle sprawnych fizycznie, że mogą przychodzić samodzielnie lub z kimś do kościoła”, tamże, s. 119. 
ludzie żyją znacznie dłużej”' Pisząc to, papież z Polski miał 79 lat; zbliżał się do osiemdziesiątki, a więc do granicy wyznaczonej osobom mocnym. Przeżył jeszcze sześć bardzo owocnych lat.

W czasie swojego pontyfikatu Jan Paweł II napisał listy apostolskie do młodych, do dzieci, a pod koniec życia - do ludzi starszych. Ten ostatni zatytułował: List do moich Braci i Sióstr - ludzi w podeszłym wieku. Ludzie w podeszłym wieku to najstarsza grupa wiekowa zaliczana do osób starszych.

Kto zaś tworzy najmłodszą grupę pośród starszych? Jeśli przyjmiemy, że ludzie dojrzale podejmują role rodzicielskie $\mathrm{w}$ wieku 25 lat, to znaczy, że rodzice takich dojrzałych rodziców stają się dziadkami w wieku 50 lat. Ludzie po 50 roku życia mają już za sobą większość doświadczeń życiowych. Po pięćdziesiątce ma się zwykle więcej życia za sobą niż przed sobą. Tak więc ludzie po pięćdziesiątce to ludzie starsi, choć najmłodsi wśród starszych, czyli w sile wieku. Wielu jest w tym wieku czynnych zawodowo i to jeszcze przez 10, 15, a nawet 20 lat. Wiek emerytalny w Polsce to 67 rok życia 7 . Profesorowie uczelni wyższych mogą pracować nawet do ukończenia 70 roku życia. W wielu diecezjach proboszczowie pracują do osiągnięcia 75 roku życia. Kardynałowie wybierają papieża do osiągnięcia 80 roku życia.

Cyceron ${ }^{8}$ określał starość jako „jesień życia”, nawiązując w ten sposób do pór roku, które następują kolejno po sobie w przyrodzie. Istnieje bowiem bliska analogia między przebiegiem życia człowieka a rytmem życia przyrody, do której człowiek się zalicza9?.

Ludzi w jesieni życia określano do niedawna także eufemistycznym mianem „ludzi trzeciego wieku”. Ostatni okres ludzkiego życia, czyli trzeci wiek w znaczeniu biologicznym i społecznym, następuje po 50 roku życia, jako że pierwszym wiekiem jest okres niedojrzałości i niepełnoletniości obejmujący dzieciństwo i wczesną młodość. Po nim następuje wiek drugi, czyli wiek średni, w którym większość ludzi zakłada rodzinę i wychowuje potomstwo. Termin ludzie "trzeciego wieku” pozwala uniknąć przypisywania tej grupie cech „emerytów” czy „rencistów”. Dziś bowiem wielu ludzi starszych prowadzi

6 Jan Paweł II, List do moich Braci i Sióstr - ludzi w podeszłym wieku (1.10.1999), nr 1. Szerzej o starości w tekstach biblijnych zob. R. Bogacz, Starość w Biblii, [w:] Starość. Problem czy szansa? Refleksja teologiczno-pastoralna, red. Jan Dziedzic, Kraków 2015, s. 13-44.

7 Ustawodawcy postanowili zmienić aktualnie obowiązujące prawo i obniżyć od 1 października 2017 r. wiek emerytalny do 60 lat dla kobiet i 65 lat dla mężczyzn.

8 Por. M. T. Cicero, Cato maior, seu De senectute, 19, 70; cyt. za: Jan Paweł II, List do moich Braci i Sióstr - ludzi w podeszłym wieku, dz. cyt., nr 5.

9 Jan Paweł II, List do moich Braci i Sióstr - ludzi w podeszłym wieku, dz. cyt., nr 5. 
życie czynne zawodowo. Na Uniwersytecie Fordham w Nowym Yorku już w 1978 utworzono centrum dla ludzi „trzeciego wieku”. Takie określenie dokonuje kwalifikacji ludzi nie na podstawie wieku, ale ich osobistych możliwości ${ }^{10}$.

Według Światowej Organizacji Zdrowia (wHo) ludzie starsi podzieleni są na trzy grupy w wieku: podeszłym (6o-75 lat), starczym (76-9o lat) i sędziwym (powyżej 90 lat) ${ }^{11}$. Nieco inaczej ujmowane są okresy życia człowieka w ujęciu ekonomicznym, w którym jako pierwszy wiek określa się okres przedprodukcyjny człowieka, a jako drugi - okres produkcyjny. Trzeci wiek w tym ujęciu jest okresem poprodukcyjnym.

Ludzie starsi to znaczna zakresowo grupa osób. Stąd Jan Paweł II różnicuje ją, mówiąc o „trzecim lub czwartym wieku” w życiu człowieka ${ }^{12}$ albo też o „ludziach w podeszłym wieku”"13. Ludzie czwartego wieku to osoby w późnej starości, czyli po 75 roku życia. Innym wreszcie określeniem człowieka w jego ostatnim etapie życia jest „człowiek sędziwy albo człowiek stary”"14.

W poniższym opracowaniu przyjmujemy szerokie określenie grupy starszych. Obejmuje ono wszystkich po 50 roku życia.

\section{Ludzie starsi w parafii}

Faktem jest, że opieka duszpasterska nad ludźmi starszymi i przepowiadanie słowa Bożego do nich dokonują się przede wszystkim w parafii ${ }^{15}$. Oni stanowią trzon parafii, rozumianej jako wspólnota wiernych wypełniająca zadanie zwiastowania słowa Bożego, jednoczenia w wierze, kulcie i miłości braterskiej ${ }^{16}$. Jak zauważają teologowie pastoralni, Kościół roztacza nad nimi opiekę duszpasterską przez „głoszenie im słowa Bożego, sprawowanie sakramentów, posługę charytatywną, a także realizację zadań integracyjnych i społecznych"17. To właśnie ludzie starsi są najczęstszymi uczestnikami codziennych mszy św. i w dużej mierze także mszy św. niedzielnych, a z tego powodu są adresatami homilii,

${ }^{10}$ R. Hart, Preacher as risk taker, Collegeville, MN 2003, s. 66.

${ }^{11}$ W. Przygoda, Wyzwania duszpasterskie wobec osób w podeszłym wieku, „Polonia Sacra” 38 (2015) nr 1, s. 72.

${ }_{12}$ Jan Paweł II, List do moich Braci i Sióstr - ludzi w podeszłym wieku, dz. cyt., nr 9.

13 Tamże, nr 12.

14 Tamże, nr 10.

${ }_{15}$ Por. W. Przygoda, Wyzwania duszpasterskie wobec osób w podeszłym wieku, dz. cyt., s. 75-92.

${ }_{16}$ Por. R. Kamiński, Duszpasterstwo w społeczeństwie pluralistycznym, Lublin 1997, s. 66.

${ }_{17}$ J. Ostrowski, W. Przygoda, Seniorów duszpasterstwo, [w:] Leksykon teologii pastoralnej, red. R. Kamiński, Lublin 2006, s. 789. 
które stanowią dla nich permanentną formację $\mathrm{w}$ wierze ${ }^{18}$. Oni wypełniają świątynię, gdy organizowane są msze św. połączone z udzielaniem sakramentu namaszczenia chorych. Oni też są częstymi uczestnikami pielgrzymek do sanktuariów i nabożeństw ludowych. Jednym $\mathrm{z}$ nich, w którym uczestniczą przede wszystkim ludzie starsi, są gorzkie żale wraz ze współtworzącym je kazaniem pasyjnym. Wszystkie formy pobożności ludowej, ze szczególnie popularnym nabożeństwem różańcowym na czele, stwarzają znakomitą okazję do zwiastowania słowa Bożego, którego ludzie starsi są szczególnie spragnieni i mają prawo oczekiwać go z ust swoich duszpasterzy ${ }^{19}$. Grupę osób starszych w parafii dostrzegła Międzynarodowa Rada do Spraw Katechezy i w dokumencie pt. Katecheza dorostych we wspólnocie chrześcijańskiej wyróżniła ich wśród odbiorców katechezy dorosłych jako pozostawionych na marginesie życia ${ }^{20}$.

Ludzie starsi mogą pełnić wiele funkcji podczas liturgii. II Polski Synod Plenarny zalecił, aby w parafiach były zespoły liturgiczne tworzone nie tylko przez przedstawicieli młodzieży i dzieci, ale także - dorosłych ${ }^{21}$. Zadaniem członków takich zespołów jest między innymi wspieranie duszpasterzy „,W określeniu tematu i treści homilii uwzględniającej potrzeby wspólnoty"². Celem zaś wzajemnej współpracy z parafialnym zespołem liturgicznym jest lepsze przygotowanie wiernych do sprawowania posług podczas obrzędów liturgicznym oraz unikanie improwizacji, która nie licuje z powagą tych obrzędów ${ }^{23}$.

Ludzie starsi w parafii mogą śpiewać $\mathrm{w}$ chórze, przynosić dary i zbierać składkę. Mogą też pełnić posługę psałterzysty, lektora, akolity ${ }^{24}$. Przy czym posługę stałych akolitów, według synodu, mogą pełnić tylko mężczyźni, którzy ukończyli przynajmniej 25 lat. Górnej granicy wieku nie ma ${ }^{25}$. Starsi mogą

${ }_{18}$ Konferencja Episkopatu Polski, Dyrektorium katechetyczne Kościoła katolickiego w Polsce, Kraków 2001, nr 102.

19 Tamże, nr 104; J. Kudasiewicz, Proforystyka pastoralna. Pismo św. jako księga ludu Bożego, [w:] Wstęp ogólny do Pisma św., red. J. Szlaga, Poznań-Warszawa 1986, s. 271-272.

${ }_{20}$ Międzynarodowa Rada do Spraw Katechezy, Katecheza dorosłych we wspólnocie chrześcijańskiej. Niektóre linie i ukierunkowania, Watykan 1990, przekład polski: przeł. K. Misiaszek, Kraków 2001, n. 55 .

${ }^{21}$ II Polski Synod Plenarny (1991-1999). Liturgia Kościoła po Soborze Watykańskim II, n. 83.

${ }_{22}$ Tamże.

23 Por. tamże.

${ }^{24}$ Por. Konferencja Episkopatu Polski, Dyrektorium duszpasterstwa służby liturgicznej, Kraków 2009, $\mathrm{nr}$ 3, 54, 105, zob. 100-146.

${ }^{25}$ II Polski Synod Plenarny (1991-1999). Liturgia Kościoła po Soborze Watykańskim II, nr 84; Konferencja Episkopatu Polski, Dyrektorium duszpasterstwa służby liturgicznej, n. 109: Formacja stałych akolitów i lektorów odbywa się w diecezji. 
ponadto pełnić posługę nadzwyczajnego szafarza komunii świętej, animatora liturgicznego, ceremoniarza, organisty, kantora, dyrygenta chóru i zakrystia$\mathrm{na}^{26}$. W miarę rozwoju zespołu liturgicznego powstaje w parafii wspólnota osób starszych wytrwale dążąca do świętości ${ }^{27}$.

Według Dyrektorium duszpasterstwa służby liturgicznej zaangażowanie dorosłych w służbę liturgiczną dokonuje się na dwa sposoby. Pierwszym jest kontynuacja posługi wykonywanej w parafii w dzieciństwie i młodości. Drugim sposobem jest podjęcie posługi liturgicznej w wieku dorosłym ${ }^{28}$. W tym drugim przypadku wskazany jest krótki okres wprowadzający ${ }^{29}$, po którym następuje trzyletnia formacja wstępna. Jej treść pokrywa się z treścią formacji młodzieżowych zespołów liturgicznych i obejmuje takie tematy, jak słowo ${ }^{30}$, sakrament $^{31}$, wspólnota ${ }^{32}$. Dla przykładu, tematyka słowa Bożego obejmuje wprowadzenie do Lekcjonarza mszalnego, w którym zawarty jest trzyletni cykl czytań mszalnych na niedziele (rok A, B i C) oraz dwuletni cykl czytań na dni powszednie (rok I i II).

\section{Ludzie starsi jako słuchacze słowa Bożego. Zainteresowanie słuchaczami słowa Bożego we współczesnej homiletyce}

Kwestia słuchaczy słowa Bożego budzi coraz większe zainteresowanie homiletów ${ }^{33}$. Co więcej, koncentracja na audytorium stała się cechą odnowy antropologicznej przepowiadaną tuż po II soborze watykańskim. Owa koncentracja na audytorium jest też cechą charakterystyczną tak zwanej „nowej homiletyki” (ang. New Homiletics), która w latach siedemdziesiątych rozwinęła się

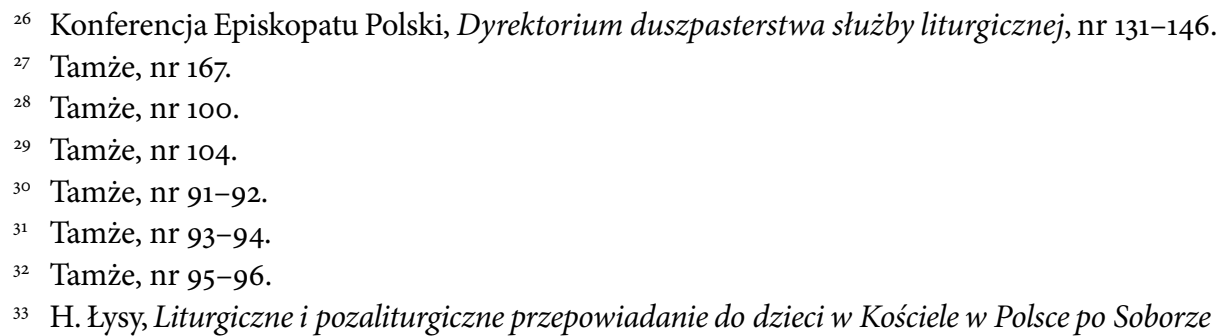
Watykańskim II. Teoria i praktyka, Opole 2011; A. Lewek, Jak głosić słowo Boże dzieciom?, „Homo Dei” 46 (1977) nr 4, s. 271-275; H. Sławiński, Kontekstualne uwarunkowanie głoszenia katechez do młodzieży, „Pro Musica Sacra” 13 (2015), s. 53-69; H. Sławiński, Msza św. i homilia według „Dyrektorium o Mszach św. z udziałem dzieci”. Aktualność dyrektorium w 4o. rocznicę powstania?, „Teologia i Człowiek” 28 (2014), s. 4, 97-115. 
w Stanach Zjednoczonych i do dziś w istotnej mierze kształtuje myśl homiletyczną. Nurt ten miał nawet wpływ na kształt dokumentu biskupów amerykańskich na temat homilii: Fulfilled in Your Hearing. Celowo dobranym punktem wyjścia dla refleksji nad homilią jest w tym dokumencie zgromadzenie słucha$\mathrm{Czy}^{34}$. Nie głosiciel, jak było to typowe w wielu wcześniejszych opracowaniach, ani nawet słowo Boże, ale właśnie odbiorcy słowa Bożego są punktem wyjścia do refleksji homiletycznej wielu autorów ${ }^{35}$. Zgromadzenie liturgiczne zostało bowiem uznane w soborowej odnowie liturgicznej za centralny znak. Autorzy dokumentu Fulfilled in Your Hearing podali nawet dwa argumenty na rzecz celowo dobranego punktu wyjścia do refleksji nad homilią. Są nimi: badania w dziedzinie komunikacji międzyludzkiej oraz współczesna eklezjologia ${ }^{36}$.

Trzeba jednak przyznać, że samo zainteresowanie określonymi grupami słuchaczy nie jest czymś nowym w homiletyce, bo już w vi wieku papież św. Grzegorz Wielki (ok. 540-604) w swojej Regule pasterskiej podał katalog słuchaczy ${ }^{37}$. Nowe natomiast jest identyfikowanie audytorium ze względu na kryteria oparte na współczesnych, ekonomicznych, psychologicznych i socjologicznych badaniach naukowych, w których wykorzystywane są m.in. analizy statystyczne.

Podejście do przepowiadania skoncentrowane na analizie słuchaczy (ang. listener-centered) bierze pod uwagę koncepcję homilii i kazania jako otwartego dzieła, a więc fakt, że ostatecznie o skuteczności przepowiadania decyduje słuchacz. Jemu przysługuje wolność religijna, a zatem również odpowiedzialność za przyjęcie lub odrzucenie orędzia Ewangelii. Świadomość tego faktu jest bardzo ważna, ponieważ głosiciel słowa Bożego może spełnić wszystkie wymagania stawiane mu przez homiletykę, retorykę i komunikację społeczną, ale i tak to słuchacz zadecyduje o tym, co uczyni podczas dokonywanych wyborów życiowych ${ }^{38}$.

${ }^{34}$ Por. Komisja do spraw życia i posługi kapłanów przy Krajowej Konferencji Biskupów Katolickich UsA, „Dziś spełniły się słowa Pisma, któreście styszeli”. Homilia w zgromadzeniu niedzielnym, [w:] Homilia niedzielna. Dokumenty Konferencji Episkopatu Stanów Zjednoczonych, przeł., oprac. i red. H. Sławiński, Kraków 2015, s. 89-135, nr 1-15.

35 Por. tamże; J. R. Nieman, T. G. Rogers, Preaching to every pew. Cross-cultural strategies, Minneapolis, MN 2001; P. J. Cameron, Why preach. Encountering Christ in God's Word, San Francisco 2009, s. 17-66.

${ }^{36}$ Komisja do spraw życia i posługi kapłanów przy Krajowej Konferencji Biskupów Katolickich usA, Dziś spełniły się słowa Pisma, któreście słyszeli, dz. cyt., nr 4-5.

${ }_{37}$ Por. J. R. Nieman, T. G. Rogers, Preaching to every pew..., dz. cyt., s. 17.

${ }^{38}$ Por. tamże. 
Niewątpliwie grupą słuchaczy słowa Bożego, która nie doczekała się jeszcze szeregu wnikliwych opracowań, są ludzie starsi. A przecież są oni szczególnie otwarci na słowa życia wiecznego: „Jeśli życie jest pielgrzymką do niebieskiej ojczyzny, to starość jest czasem, gdy jesteśmy najbardziej skłonni myśleć o wieczności”39. Jan Paweł II zauważył, że „W miarę jak wzrastać będzie średnia długość życia, a w konsekwencji także liczba ludzi starych, coraz bardziej konieczne będzie krzewienie kultury, która akceptuje i ceni starość, a nie spycha jej na margines społeczeństwa" ${ }^{40}$. Istnieją bowiem koncepcje utylitarystyczne, które całkowicie marginalizują ludzi starszych jako mało użytecznych społecznie. Papież Franciszek w ostrych słowach piętnuje utylitaryzm w podejściu do ludzi najsłabszych: „Kultura relatywizmu jest tą samą patologią, która pobudza daną osobę do wykorzystywania innej i potraktowania jej jedynie jako przedmiotu, zmuszając ją do pracy przymusowej lub sprowadzając do niewolnictwa za długi. Jest to ta sama logika, która prowadzi do porzucenia osób starszych, które nie służą naszym interesom, czy do wykorzystywania seksualnego dzieci" ${ }^{41}$.

Elementem kultury, która ceni starość, jest przepowiadanie słowa Bożego. Warto ten fakt zauważyć i wyartykułować.

\section{Treść przepowiadania do ludzi starszych}

Najogólniej przyjmując, Kodeks prawa kanonicznego, za nauczaniem soborowym, najpierw podaje ogólne stwierdzenie o tym, że „głosiciele słowa Bożego powinni przedstawiać wiernym przede wszystkim to, w co należy wierzyć i co trzeba czynić dla chwały Bożej i zbawienia ludzi”"42. Następnie zaś uszczegóławia nauczanie soborowe na temat tego, co słudzy słowa mają głosić wiernym: „Niech także przekazują wiernym naukę, jaką Urząd Nauczycielski Kościoła głosi o godności i wolności osoby ludzkiej, o jedności i trwałości rodziny oraz o jej zadaniach, o obowiązkach ludzi żyjących w społeczeństwie, jak również o układaniu spraw doczesnych zgodnie z porządkiem ustanowionym przez Boga"43.

39 Jan Paweł II, List do moich Braci i Sióstr - ludzi w podeszłym wieku, dz. cyt., nr 14.

40 Tamże, $\mathrm{nr} 13$.

${ }^{41}$ Franciszek, Encyklika Laudato si, 123; por. J. Dziedzic, Kościół wobec starości. Perspektywa pastoralnoteologiczna, „Polonia Sacra” 38 (2015) nr 1, s. 97.

${ }^{42}$ Kodeks prawa kanonicznego, kan. $768 \$ 1$.

43 Tamże, kan. $768 \S 2$. 
Podobnie w homiletyce współczesnej wśród podstawowych źródeł decydujących o treści przepowiadania wymienia się: teksty biblijne, liturgiczne, nauczanie Kościoła oraz doświadczenie słuchaczy ${ }^{44}$. Tym więc, co przede wszystkim decyduje o specyfice przepowiadania do ludzi starszych, jest bogate, wieloletnie doświadczenie życiowe.

Analizując adresatów homilii, biskupi amerykańscy zauważyli przed laty:

Jeśli kaznodzieje mają znać i rozumieć swoje dzisiejsze zgromadzenia wiernych, konieczna może być pewna znajomość popularnych form rozrywki. Nie potrzeba spędzać całego popołudnia na oglądaniu „oper mydlanych”, zapamiętywaniu statystyk z rozgrywek sportowych albo słuchaniu ostatnich przebojów. Jeśli jednak jesteśmy całkowicie nieświadomi bądź robimy wrażenie, że jesteśmy nieświadomi, w jaki sposób ludzie spędzają czas, jakie są ich zainteresowania, pochłaniające większość wolnego czasu, energii i pieniędzy, byłoby nam trudno uchwycić relacje pomiędzy ich życiem i Ewangelią albo wezwać ich do pełniejszej, bogatszej i głębszej odpowiedzi wiary ${ }^{45}$.

Słowa te odnoszą się również do ludzi starszych, którzy są najczęściej słuchaczami homilii, zwłaszcza homilii głoszonych w zwykłe dni tygodnia ${ }^{46}$.

Pisząc na temat przepowiadania dotyczącego ludzi starszych, amerykański homileta, Richard Hart of M Cap, wymienia następujące zagadnienia, które powinny być wzięte pod uwagę: izolacja, szacunek do starszych w różnych tradycjach, wyzwania starszego wieku, paradoks, cykliczność, poczucie humoru ${ }^{47}$.

Izolacja nie jest zaliczana w periodykach medycznych do chorób, ale wykazano, że sprzyja ich powstawaniu. Poważna izolacja człowieka powoduje zwykle poważne problemy. Wiemy zaś, że zgodnie z Bożym planem, nie jest dobrze, żeby człowiek był sam (por. Rdz 2, 18). Alternatywą wobec izolacji jest integracja starszych z parafią przez przynależność do jednej albo nawet kilku wspólnot w parafii, jak na przykład Koło Żywego Różańca, chór parafialny, parafialne grupy Caritas. Przynależność do wspólnoty stwarza okazję

${ }_{44}$ Por. W. Broński, Homilia, [w:] Leksykon teologii pastoralnej, red. R. Kamiński, Lublin 20o6, S. $288-291$.

45 Komisja do spraw życia i posługi kapłanów przy Krajowej Konferencji Biskupów Katolickich Us A, „Dziś spetnity się słowa Pisma, któreście styszeli”, dz. cyt., nr 33.

${ }^{46}$ Por. W. Przygoda, Formacja apostolska ludzi w podeszłym wieku, „Perspectiva” 1 (2009), S. $181-182$.

47 R. Hart, Preacher as risk taker, dz. cyt., s. 66-73. 
do nawiązywania nowych znajomości i pielęgnowania przyjaźni, co z kolei może sprawić, że "trzeci wiek” stanie się pięknym okresem życia ${ }^{48}$.

Trzeci czy czarty okres życia może być przeżywany bardzo owocnie. Wiedział o tym autor psalmu, gdy pisał: „Zasadzeni w domu Pańskim rozkwitną na dziedzińcach naszego Boga. Wydadzą owoc nawet i w starości, pełni soków i zawsze żywotni, aby świadczyć, że Pan jest sprawiedliwy" (Ps 92, 13-16).

Szacunek do starszych można odnaleźć w różnych tradycjach. Ludzie starsi w szczególny sposób zasługują na szacunek, zarówno ze względu na swój wieloletni wkład w życie społeczne, jak i ze względu na postępującą słabość. Szacunek do starszych podkreślany był w różnych tradycjach kulturowych już w starożytności. Grecki poeta Fokilides zachęcał: „Szanuj siwe włosy, a mądrego starca otaczaj czcią jak własnego ojca”" ${ }^{4}$. Kilkaset lat później „łaciński poeta Owidiusz pisał, że «wielka była niegdyś cześć dla siwej głowy»" ${ }^{\circ 0}$. W Indiach wiek ludzi dzielony jest na dwie części. Pierwsza nazywana jest wiekiem domowym, druga czasem rozwoju duchowego. W hinduizmie nie podkreśla się słabości ludzi starszych, ale ich duchową dojrzałość. We wspólnotach afroamerykańskich do dziś ważną rolę pełnią osoby starsze, z których zdaniem trzeba się liczyć. Wyznawcy konfucjanizmu traktują szacunek do starszych jako główną zasadę moralną, której przestrzeganie gwarantuje harmonię i pokój w świecie. Konfucjusz uczył, że w młodości człowiek musi zmagać się ze zmysłowością, $\mathrm{w}$ średnim wieku $\mathrm{z}$ agresją $\mathrm{w}$ dochodzeniu do wyznaczonych sobie celów, a w starości ze skąpstwem i nadmiernym przywiązaniem do posiadanych rzeczy, a nawet do własnego życia ${ }^{51}$. Japończycy porównują życie człowieka do pór roku w przyrodzie, dostrzegając w każdej z nich swoiste piękno. Tym, co według nich charakteryzuje ludzi starszych, jest wewnętrzny spokój ${ }^{52}$.

Jan Paweł II dostrzega we współczesnym świecie zarówno oznaki szacunku do starszych, jak i postawę przeciwną:

Jeśli spróbujemy przyjrzeć się obecnej sytuacji, przekonamy się, że w niektórych społeczeństwach starość jest ceniona i poważana, w innych zaś cieszy się znacznie

48 Tamże, s. 66-67.

49 Fokilides, Sentencje, XLII; cyt. za: Jan Paweł II, List do moich Braci i Sióstr - ludzi w podeszłym wieku, dz. cyt., nr 9.

5o Magna fuit quondam capitis reverentia cani - Owidiusz, Fasti, v, w. 57; cyt. za: Jan Paweł II, List do moich Braci i Sióstr - ludzi w podeszłym wieku, dz. cyt., nr 9.

${ }_{51}$ Por. R. Hart, Preacher as risk taker, dz. cyt., s. 68.

${ }_{52}$ Por. tamże, s. 69. 
mniejszym szacunkiem, ponieważ panująca tam mentalność stawia na pierwszym miejscu doraźną przydatność i wydajność człowieka. Pod wpływem tej postawy tak zwany trzeci lub czwarty wiek jest często lekceważony, a sami ludzie starsi muszą zadawać sobie pytanie, czy ich życie jest jeszcze użyteczne ${ }^{53}$.

Słusznie więc Jan Paweł I podkreślał, „że cechą cywilizacji prawdziwie ludzkiej jest szacunek i miłość do ludzi starych" ${ }^{4}$. Musi ona znaleźć wyraz również w sposobie przepowiadania. Szacunek do starszych powinien być wyrażony szczególnie w przykładach stosowanych w przepowiadaniu. Można w różnych sytuacjach podkreślać walory, jakie ludzie starsi wnoszą w życie społeczne, dzięki posiadanemu doświadczeniu życiowemu, które jest nie mniej cenne niż wykształcenie uniwersyteckie.

Wyzwaniem dla ludzi starszych jest ciągły rozwój. Mędrzec Syrach dostrzega potrzebę rozwijania dobrych nawyków w młodości i kontynuowania ich w starości: „Synu, od młodości swej staraj się o naukę, a będziesz ja nabywał aż do siwizny" (Syr 6, 18). Abraham Joshua Heschel zauważył, że starość nie musi oznaczać braku świeżości. Ważne jest ciągłe zdobywanie mądrości, które z kolei daje wewnętrzne poczucie bezpieczeństwa, ponieważ samo istnienie jest błogosławieństwem - po prostu życie jest święte ${ }^{55}$. Podobnie postrzegał starość Jan Paweł ir. Przypomniał, że starość to czas, w którym wszystko sprzyja temu, aby człowiek mógł „najlepiej pojąć sens życia i zdobyć «mądrość serca». «Starość jest czcigodna - czytamy w Księdze Mądrości - nie przez długowieczność i liczbą lat się jej nie mierzy: sędziwością u ludzi jest mądrość, a miarą starości - życie nieskalane» (4, 8-9). Starość to ostatni etap ludzkiego dojrzewania i znak Bożego błogosławieństwa" ${ }^{56}$.

Carl Gustav Jung zauważa, że w drugiej połowie życia należy troszczyć się o wewnętrzny rozwój, który określa jako osiąganie pełni swojego potencjału ${ }^{57}$. Ludzie starsi bardziej uświadamiają sobie, że są pielgrzymami, przechodniami wezwanymi do kenozy, do wyzbywania się wielu cennych posiadłości. Zaznaczając, w jaki sposób Piotr uwielbi Boga, Pan Jezus powiedział: „Gdy byłeś młodszy, opasywałeś się sam i chodziłeś, gdzie chciałeś. Ale gdy się zestarzejesz, wyciągniesz ręce swoje, a inny cię opasze i poprowadzi, dokąd nie chcesz"

\footnotetext{
53 Jan Paweł II, List do moich Braci i Sióstr - ludzi w podeszłym wieku, dz. cyt., nr 9.

54 Tamże, nr 12.

55 Por. R. Hart, Preacher as risk taker, dz. cyt., s. 69.

${ }_{56}$ Por. Jan Paweł II, List do moich Braci i Sióstr - ludzi w podeszłym wieku, dz. cyt., nr 8.

57 Por. R. Hart, Preacher as risk taker, dz. cyt., s. 70.
} 
$(J$ 21, 18). Podobny los jest udziałem wielu starszych osób, które muszą się liczyć z liczbymi przeciwnościami życiowymi, z trudnymi doświadczeniami. Coraz bardziej upodobniają się do Jezusa w centrum Jego misterium paschalnego. Dorastają do tego, by powiedzieć za św. Pawłem: „Tymczasem ja dla Prawa umarłem przez Prawo, aby żyć dla Boga: razem z Chrystusem zostałem przybity do krzyża" (Ga 2, 19) $)^{58}$.

Paradoksem jest to, że jako ludzie jesteśmy zarazem śmiertelni i nieśmiertelni. Żeby wszystko zyskać, trzeba wszystko stracić. Jakże często ludzie bogaci ulegają zniechęceniu i znudzeniu, podczas gdy ubodzy potrafią się cieszyć życiem. Przynajmniej do pewnego stopnia ludzie starsi mogą wybrać, jakimi chcą być: życzliwymi, kochającymi i wyrozumiałymi bądź cynicznymi, irytującymi, pesymistycznymi i zrzędliwymi. Pomocą dla człowieka w jego samorozwoju jest Bóg, do którego trzeba zawsze się zwracać w pokornej i ufnej modlitwie, jakiej przykład dał nam psalmista: „Boże, Ty mnie uczyłeś od mojej młodości, i do tej chwili głoszę Twoje cuda. Lecz i w starości, i w wieku sędziwym nie opuszczaj mnie, Boże" (Ps 71, 17-18)

Paradoksem jest to, że można wciąż rozwijać się i dojrzewać, pomimo jednoczesnej utraty sił i rosnącej niepełnosprawności. Zamiast mówić o tym, że starzejemy się z każdym dniem, można - paradoksalnie - powiedzieć, że z każdym dniem stajemy się nowi ${ }^{60}$.

Może to brzmi paradoksalnie, ale ludziom starszym należy mówić bardziej o życiu niż o śmierci, ale o życiu w jego integralności. Trzeba bowiem patrzeć na życie w całości, a takie spojrzenie możliwe jest tylko przy uwzględnieniu wieczności, która jest właściwą perspektywą człowieka. Każdy etap ludzkiego życia jest przygotowaniem do życia wiecznego. „Jeśli życie jest pielgrzymką do niebieskiej ojczyzny, to starość jest czasem, gdy jesteśmy najbardziej skłonni myśleć o wieczności”" ${ }^{\text {. }}$.

Najlepszym przygotowaniem do niej jest dobrze przeżyte życie doczesne. Jak zauważył Jan Paweł II: „[...] czas trzeba twórczo spożytkować, dążąc do pogłębienia życia duchowego przez usilniejszą modlitwę i gorliwą służbę braciom w miłości. Zasługują zatem na uznanie wszystkie inicjatywy społeczne, dzięki którym ludzie starzy mogą nie tylko dbać o swoją kondycję fizyczną

${ }_{58}$ Por. tamże.

59 Por. tamże, s. 71.

${ }^{60}$ Por. tamże, s. 72; P. Morciniec, Starzeć się z godnością. Od doświadczenia straty do owocowania, „Polonia Sacra” 38 (2015) nr 1, s. 60-65.

${ }^{61}$ Jan Paweł II, List do moich Braci i Sióstr - ludzi w podeszłym wieku, dz. cyt., nr 14. 
i intelektualną oraz rozwijać relacje z innymi, ale także stawać się przydatni, oddając innym swój czas, umiejętności i doświadczenie"62. Tak więc można zachęcać starszych do aktywności społecznej oraz głębokiej, bliskiej i ufnej relacji z Bogiem.

Nasze życie naznaczone jest cyklicznością, tak jak rok liturgiczny. Nie oznacza to, że cokolwiek w życiu się powtarza. Graficzną ilustracją życia jest nie koło, ale spirala. W ciągu życia pojawiają się choroby, doskwierają bóle, przerywane chwilami przemijających radości i poczucia szczęścia, ale za każdym razem jest to inna choroba i ból, inna radość i szczeście. Święty Paweł doświadczył w swoim życiu wielu cierpień (por. 2 Kor 11, 23-29). Doskwierał mu nawet „oścień dla ciała” (2 Kor 12, 7), który permanentnie odczuwał. Z czasem jednak nauczył się akceptować swoją słabość: „Jeżeli już trzeba się chlubić, będę się chlubił z moich słabości” (2 Kor 11, 30). Pan Jezus zapewnił go bowiem: „Wystarczy ci mojej łaski” (2 Kor 12, 9) ${ }^{63}$.

Niezwykle pomocne w życiu jest poczucie humoru, które należy nieustannie pielęgnować i rozwijać, również w podeszłym wieku. Pomaga ono w przezwyciężaniu konfliktów i dodaje sił do przezwyciężenia trudów codziennego życia. Poczucie humoru jest znakiem dojrzałości, której można oczekiwać od osób starszych. Ono pomaga spokojnie i ze słusznym dystansem podejść do rozmaitych problemów i sprawia, że osoba staje się bardziej przystępna dla tych, którzy są gotowi przyjść jej z pomocą ${ }^{64}$.

Treścią, jaką warto podejmować w przepowiadaniu do starszych, są refleksje nad życiem i przemianami w Kościele. Będąc w podeszłym wieku, Jan Paweł II nadmienił: ,jest naturalne w naszym wieku, że powracamy do przeszłości, aby dokonać swoistego bilansu. Takie spojrzenie wstecz pozwala na spokojniejszą i bardziej obiektywną ocenę ludzi i sytuacji, z jakimi zetknęliśmy się w życiu"65.

\section{Sposób i okoliczności przepowiadania do ludzi starszych}

Starsi zasługują na szacunek wyrażony także w formie przepowiadania. Nietaktem na przykład, przynajmniej w kulturze polskiej, byłoby zwracanie się młodego księdza do ludzi starszych w drugiej osobie liczby pojedynczej: „ty”.

\footnotetext{
62 Tamże, nr 16.

${ }_{63}$ Por. R. Hart, Preacher as risk taker, dz. cyt., s. 72.

${ }_{64}$ Por. tamże, s. 72-73.

${ }_{65}$ Jan Paweł II, List do moich Braci i Sióstr - ludzi w podeszłym wieku, dz. cyt., nr 2.
} 
Również obcesowe, szczegółowe pouczanie, co mają robić, byłoby brakiem szacunku dla ich inteligencji i osobistych doświadczeń. Święty Paweł zostawił Kościołowi szczegółowe wskazanie, by w przepowiadaniu do starszych zachować maksymalną subtelność. Przekazując rady pastoralne biskupowi Tymoteuszowi, zaznaczył: „Starszego wiekiem nie strofuj, lecz nakłaniaj prośbą jak ojca, młodszych - jak braci, starsze kobiety - jak matki; młodsze - jak siostry, z całą czystością! Miej we czci te wdowy, które są rzeczywiście wdowami” (1 $\operatorname{Tm} 5,1-3)$.

Henri Nouwen (1932-1996) przestrzega, że nasza troska o to, by przepowiadać i pouczać, powstrzymuje nas od przyjęcia tego, co starsi mają do zaoferowania. Dlatego ten doświadczony autor radzi, by w kontakcie ze starszymi nie rozpoczynać od stawiania sobie pytania o to, jak im pomóc, ale raczej o to, jak uczynić starszych centrum swojego życia, w jaki sposób dopuścić ich do głosu i wysłuchać ich z uwagą ${ }^{66}$. Potem można dopuścić ich do głosu w sposób realny, pozwalając na krótkie świadectwo, albo też w sposób wirtualny - nawiązując do ich wypowiedzi i bogatych doświadczeń.

Co do dialogu realnego ze słuchaczami starszymi, zdania homiletów są podzielone. Adam Kalbarczyk twierdzi: „Ludzie starzy na ogół nie lubią zmian i innowacji w swoim otoczeniu; wolą pozostać przy tym, co znają, i wiedzą, jak należy z tym postępować. Nie wyklucza to jednak roztropnego stosowania innych, nowych form głoszenia słowa Bożego, jak np. świadectwa czy homilie dialogowane" ${ }^{\text {"67}}$. Odmienne stanowisko uzasadnia Edward Staniek, pisząc: „Nie można prowadzić dialogu na ambonie ani z młodzieżą, ani z słuchaczami dorosłymi. Gubi się wówczas profetyczny wymiar przepowiadania. Dorośli zamiast pytać, podają swoje wyjaśnienia, a te nie interesują słuchaczy, są bowiem tylko indywidualnym głosem w dyskusji. Na dialog z dorosłymi trzeba znaleźć miejsce i czas przed kazaniem lub po kazaniu. Jest on niezwykle twórczy w doskonaleniu komunikacji między kaznodzieją i słuchaczem" ${ }^{\prime \prime}$.

Przy tej kwestii trzeba pamiętać o różnicy między homilią, stanowiącą część liturgii, oraz kazaniem głoszonym podczas nabożeństw ludowych. Według instrukcji Ecclesie de mysterio, dotyczącej przepowiadania podczas liturgii, a więc również homilii:

\footnotetext{
${ }_{66}$ Por. R. Hart, Preacher as risk taker, dz. cyt., s. 69.

67 Por. A. Kalbarczyk, „Nie odtrącaj mnie w starości”..., dz. cyt., s. 119.

${ }^{68}$ E. Staniek, Z kaznodziejskiego warsztatu, Kraków 1997, s. 116.
} 
Dopuszczalne jest wprowadzenie do liturgii krótkiego komentarza, pozwalającego ją lepiej zrozumieć, a także - w wyjątkowych przypadkach - ewentualnych świadectw, które powinny być zawsze dostosowane do przepisów liturgicznych i składane podczas liturgii eucharystycznych sprawowanych ze szczególnych okazji (np. dzień seminarium, dzień chorego itp.), jeśli rzeczywiście mogą one być przydatne do zobrazowania homilii wygłoszonej jak zwykle przez celebransa. Te komentarze i świadectwa nie powinny przybierać takiej formy, która zatarłaby różnicę między nimi a homilią.

Możliwość „dialogu” podczas homilii może być czasem roztropnie wykorzystywana przez kapłana sprawującego Mszę św. jako forma objaśnienia, co jednak nie oznacza złożenia na innych obowiązku głoszenia słowa ${ }^{69}$.

Nie ma takich ograniczeń w przypadku kazań. Dlatego możliwe jest roztropne wykorzystanie dialogu również ze starszymi. Warto jednak pamiętać, że wolą oni tradycyjne formy przekazu, jak na przykład dobrze przemyślane homilie niedzielne i świąteczne oraz nauki rekolekcyjne, które wprowadzają $\mathrm{w}$ atmosferę modlitwy i adoracji ${ }^{70}$.

Wartościowym sposobem przekazu do starszych są kazania katechizmowe, które zakładają cykliczność. Edward Staniek ${ }^{71}$ zauważa, iż „dorosły katolik winien nie tylko $\mathrm{z}$ dumą prezentować wartości ewangeliczne, ale winien również umieć odeprzeć każdy zarzut, jaki jest wysuwany pod jego adresem”. Toteż Staniek promuje kazania katechizmowe, które zawierają wymiar apologetyczny. Jego zdaniem ten wymiar kazań „cieszy się niezwykle życzliwym i wdzięcznym odbiorem"72. Jest on także cechą charakterystyczną odróżniającą przepowiadanie do dzieci i do starszych. „Dziecku przekazuje się pozytywny obraz świata. Nie ma w nim miejsca na doskonalenie taktyki obronnej. Dziecko bowiem posiada poczucie bezpieczeństwa oparte na bliskości dorosłych"73.

69 Kongregacja ds. Duchowieństwa, Papieska Rada ds. Świeckich, Kongregacja Nauki Wiary, Kongregacja ds. Kultu Bożego i Dyscypliny Sakramentów, Kongregacja ds. Biskupów, Kongregacja ds. Ewangelizacji Narodów, Kongregacja ds. Instytutów Życia Konsekrowanego i Stowarzyszeń Życia Apostolskiego, Papieska Rada ds. Interpretacji Tekstów Prawnych, Instrukcja o niektórych aspektach dotyczących współpracy wiernych świeckich w ministerialnej posłudze kapłanów Ecclesiae de Mysterio (15.08.1997), AAs 89 (1997), s. 852-877, tekst polski: „L'Osservatore Romano”, wyd. pol., 12 (1998), s. 30-40; art. 3, \$ 2-3.

7o Por. E. Staniek, Z kaznodziejskiego warsztatu, dz. cyt., s. 126.

${ }_{71}$ Tamże, s. 95.

72 Tamże.

73 Tamże, s. 99. 
To od dorosłych, zwłaszcza od starszych, należy oczekiwać odpowiedzialności za przekaz wiary następnym pokoleniom. Budowanie takiej świadomości nie jest łatwe, ale pozostaje koniecznością. Edward Staniek, wypowiadając się na temat przepowiadania, z emfazą stwierdza: „Należy zawsze pamiętać, że Chrystus chętnie błogosławił dzieci, a nie zajmował się ich katechezą. W starożytnym Kościele dzieło nauczania dziecka spoczywało w rękach rodziców, a nie kapłanów. Zaangażowanie wielkich sił i czasu w katechezę dziecka może zagrażać Kościołowi infantylizmem. Harmonia między katechezą dzieci i dorosłych musi być zachowana"74.

Starsi są najczęściej słuchaczami kazań, które Staniek ${ }^{75}$ określa mianem najbardziej prestiżowych, to jest kazań pasyjnych oraz kazań podczas procesji żałobnej w Uroczystość Wszystkich Świętych. Należą one również do kazań najdłuższych. Mogą trwać nawet 20 minut.

Jeśli chodzi o okoliczności przepowiadania do starszych, stosowną okazją są rekolekcje, w czasie których wyszczególnione są grupy adresatów ze względu na wiek. Oprócz specjalnych spotkań z dziećmi i młodzieżą można przewidzieć spotkanie ze starszymi połączone $\mathrm{z}$ dobrze przygotowanym kazaniem tematycznym.

Ludzie starsi są najczęściej słuchaczami niedzielnych i codziennych homilii. Są spragnieni przepowiadania, które stanowi „pokarm konieczny dla podtrzymania chrześcijańskiego życia" ${ }^{\text {"6 }}$.

Inną sposobnością przepowiadania do starszych są homilie związane z przeżywanymi jubileuszami małżeństwa czy kapłaństwa. Można wówczas zauważyć, że dojrzały wiek „to czas szczególnie nacechowany mądrością, którą zwykle przynoszą z sobą lata doświadczeń" "77. Z czasem szeregi krewnych, przyjaciół i znajomych stają się coraz bardziej przerzedzone. Jest za kogo prosić i dziękować.

Słusznie Benedykt XV I napisał, że „choć w centrum relacji między słowem Bożym i sakramentami znajduje się niewątpliwie Eucharystia, to należy jednak podkreślić znaczenie Pisma świętego także w innych sakramentach, w szczególności w tych, które wiążą się z uzdrowieniem, czyli w sakramencie pojednania albo pokuty oraz w sakramencie namaszczenia chorych"78. Zwłaszcza

74 Tamże.

75 Tamże, s. 121.

${ }^{76}$ Kongregacja Kultu Bożego i Dyscypliny Sakramentów, Nowe ogólne wprowadzenie do Mszału rzymskiego. Z trzeciego wydania Mszału rzymskiego (18.03.2002), Poznań 2004, 65.

77 Jan Paweł II, List do moich Braci i Sióstr - ludzi w podeszłym wieku, dz. cyt., nr 5.

78 Benedykt Xvi, Verbum Domini, 61. 
w tym ostatnim przypadku warto pamiętać, że „liczne stronice Pisma świętego opisują pociechę, umocnienie i uzdrowienie, będące efektem działania Boga"79. Przepowiadanie czerpiące z Pisma św. może pomóc ludziom starszym, jakże często naznaczonym stygmatem cierpienia, przeżywać cierpliwie i z wiarą ograniczenia wieku „w jedności z odkupieńczą ofiarą Chrystusa, który wyzwala nas od zła"so.

Ważnym elementem formalnym przepowiadania do starszych jest mówienie głośne i wyraźne. Wielu bowiem starszych ma kłopoty ze słuchem. Ponadto należy zadbać o poprawny, inkluzywny język, który nikogo nie rani ani nie pomija.

\section{Głosiciel słowa Bożego do starszych}

Naturalne jest, że o ile do dzieci łatwiej jest przepowiadać młodemu duszpasterzowi, to do starszych - kapłanowi, który sam jest wiekowy i ma bogate życiowe doświadczenie, zna smak sukcesu i gorycz porażki, niszczącą siłę grzechu i radość życia w łasce uświęcającej. Nie oznacza to, że młody kapłan nie może przepowiadać do starszych. Owszem, jest to wielokrotnie konieczne. $\mathrm{W}$ takim przypadku potrzeba ze strony kapłana pokory i skromności, szacunku i bojaźni Bożej wymaganej przez tekst natchniony Pisma Świętego: „Przed siwizną wstaniesz, będziesz szanował oblicze starca, w ten sposób okażesz bojaźń Bożą" (Kpł 19, 32).

Młodym duszpasterzom, którzy mogą być zakłopotani, mając przed sobą ludzi dojrzalszych od siebie, z pomocą przychodzi Jan Paweł II, który wezwał młodych, aby traktowali starszych wielkodusznie i z miłością. Papież motywował, że starsi potrafią ubogacić młodych w sposób przekraczający wyobraźnię ${ }^{81}$. Ponadto przypomniał fragmenty Księgi Mądrości Syracha, w których znajdują się wartościowa sugestie na ten temat: „ "Nie odsuwaj od siebie opowiadania starców, albowiem i oni nauczyli się go od swoich ojców» $(8,9)$; «Stań na zgromadzeniu starszych: a [jeśli] kto jest mądry, przyłącz się do niego!» $(6,34)$, ponieważ «starcom przystoi mądrość» $(25,5)$ »82.

Podobnie uważa papież Franciszek, zachęcając młodych do słuchania starszych, gdyż wnoszą oni „pamięć i mądrość doświadczenia, która zachęca,

\footnotetext{
79 Tamże.

8o Tamże.

${ }^{81}$ Por. Jan Paweł II, List do moich Braci i Sióstr - ludzi w podeszłym wieku, dz. cyt., nr 12.

82 Tamże.
} 
by głupio nie powtarzać tych samych błędów z przeszłości”. Jednocześnie zachęca starszych do słuchania młodych, bo oni wzywają do „rozbudzenia i pogłębienia nadziei, ponieważ noszą w sobie nowe tendencje ludzkości”, a zarazem otwierają starszych na przyszłość, aby „nie byli zakotwiczeni w nostalgii za strukturami i zwyczajami, które nie są już życiodajne w dzisiejszym świecie" ${ }^{\prime 3}$.

Demografowie wykazują, że w naszym społeczeństwie przybywa i będzie nadal przybywać ludzi trzeciego i czwartego wieku. Należy zatem z coraz większą uwagą poświęcać czas tej grupie społecznej, do której sami już należymy albo wkrótce będziemy należeć. Zadaniem głosicieli słowa Bożego jest poznawanie świata ludzi starszych przede wszystkim przez częste spotkania z nimi. Starość należy postrzegać nie jako problem, ale jako szansę.

\section{ABstrakT}

\section{Przepowiadanie do ludzi w podeszłym wieku}

Wiele uwagi poświęca się w homiletyce i przepowiadaniu dzieciom. Nieproporcjonalnie mało uwagi poświęca się natomiast osobom starszym. Niniejsze opracowanie uzupełnia ten brak. Najpierw podjęta jest próba opisu, kim są ludzie starsi, następnie omówione jest ich miejsce w życiu parafialnym. W dalszej kolejności podjęta jest analiza ludzi starszych jako audytorium kościelnego przepowiadania. W konsekwencji omówione są najważniejsze kwestie egzystencjalne, które dotyczą tej grupy słuchaczy, sposób i okoliczności przepowiadania do nich oraz postawa głosiciela wobec takiego audytorium.

\section{SŁOWA KLUCzowe}

przepowiadanie, homilia, ludzie starsi, starsi słuchacze

${ }_{33}$ Franciszek, Evangelii Gaudium, 108; por. A. Kalbarczyk, „Nie odtrącaj mnie w starości”..., dz. cyt., s. 121-122. 


\section{Abstract}

\section{Preaching to the elderly}

Much attention is given to children in homiletics and preaching. Disproportionately little attention is given to the elderly in these same fields. This study supplements this deficiency. The reflection begins with an attempt to describe who the elderly are, followed by a discussion on their place in the life of the parish. An analysis of the elderly as an audience in church preaching is undertaken next. Subsequently, the most important existential issues that relate to this group of listeners is discussed, followed by the manner and circumstances of preaching to them. The publication concludes with a reflection on the attitude of the preacher towards this audience.

\section{KEYWORDS}

preaching, homily, elderly, older listeners

\section{BIBLIOGRAFIA}

\section{Źródła}

Benedykt XVI, Adhortacja apostolska Verbum Domini (30.09.2010).

Konferencja Episkopatu Polski, Dyrektorium duszpasterstwa służby liturgicznej, Kraków 2009.

Franciszek, Encyklika Laudato si' poświęcona trosce o wspólny dom (24.05.2015). II Polski Synod Plenarny (1991-1999). Liturgia Kościoła po Soborze Watykańskim II, Poznań 2001.

Jan Paweł II, List do moich Braci i Sióstr - ludzi w podeszłym wieku (1.10.1999). Kodeks prawa kanonicznego, Poznań 1983.

Komisja do spraw życia i posługi kapłanów przy Krajowej Konferencji Biskupów Katolickich Us A, „Dziś spetniły się słowa Pisma, któreście styszeli”. Homilia w zgromadzeniu niedzielnym, [w:] Homilia niedzielna. Dokumenty Konferencji Episkopatu Stanów Zjednoczonych, przeł., oprac. i red. H. Sławiński, Kraków 2015, s. 89-135. Konferencja Episkopatu Polski, Dyrektorium katechetyczne Kościoła katolickiego $w$ Polsce, Kraków 2001.

Kongregacja ds. Duchowieństwa, Papieska Rada ds. Świeckich, Kongregacja Nauki Wiary, Kongregacja ds. Kultu Bożego i Dyscypliny Sakramentów, Kongregacja ds. Biskupów, Kongregacja ds. Ewangelizacji Narodów, Kongregacja ds. Instytutów Życia Konsekrowanego i Stowarzyszeń Życia Apostolskiego, Papieska Rada ds. Interpretacji Tekstów Prawnych, Instrukcja o niektórych aspektach dotyczących 
współpracy wiernych świeckich w ministerialnej posłudze kapłanów Ecclesiae de Mysterio (15.08.1997), AAs 89 (1997), s. 852-877, tekst polski: „L'Osservatore Romano", wyd. pol., 12 (1998), s. 30-40; art. 3, \$2-3.

Kongregacja Kultu Bożego i Dyscypliny Sakramentów, Nowe ogólne wprowadzenie do Mszału rzymskiego. Z trzeciego wydania Mszału rzymskiego (18.03.2002), Poznań 2004.

Międzynarodowa Rada do Spraw Katechezy, Katecheza dorostych we wspólnocie chrześcijańskiej. Niektóre linie i ukierunkowania, Watykan 1990, przekład polski: przeł. K. Misiaszek, Kraków 2001.

\section{Literatura}

Bogacz R., Starość w Biblii, [w:] Starość. Problem czy szansa? Refleksja teologiczno-pastoralna, red. Jan Dziedzic, Kraków 2015, s. 13-44.

Broński W., Homilia, [w:] Leksykon teologii pastoralnej, red. R. Kamiński, Lublin 2006, s. 288-291.

Cameron P. J. op, Why preach. Encountering Christ in God's Word, San Francisco 2009.

Dziedzic J., Kościół wobec starości. Perspektywa pastoralnoteologiczna, „Polonia Sacra” 38 (2015) $\mathrm{nr}$ 1, s. 95-113.

Hart R. OF M Cap., Preacher as risk taker, Collegeville, MN 2003.

Kudasiewicz J., Proforystyka pastoralna. Pismo św. jako ksiegga ludu Bożego, [w:] Wstęp ogólny do Pisma św., red. J. Szlaga, Poznań-Warszawa 1986, s. 221-275.

Kalbarczyk A., „Nie odtrącaj mnie w starości”. O potrzebie profilowanego przepowiadania dla seniorów, „Polonia Sacra” 38 (2015) nr 1, s. 115-130.

Kamiński R., Duszpasterstwo w społeczeństwie pluralistycznym, Lublin 1997.

Lewek A., Jak głosić słowo Boże dzieciom?, „Homo Dei” 46 (1977) nr 4, s. 271-275.

Lewek A., Wspótczesna odnowa kaznodziejstwa. Zarys homiletyki ogólnej, z. 2, Warszawa 1980.

Łysy H., Liturgiczne i pozaliturgiczne przepowiadanie do dzieci w Kościele w Polsce po Soborze Watykańskim II. Teoria i praktyka, Opole 2011.

Morciniec P., Starzeć się z godnością: od doświadczenia straty do owocowania , Polonia Sacra" 38 (2015) nr 1, s. 49-69.

Nieman J. R., Rogers T. G., Preaching to every pew. Cross-cultural strategies, Minneapolis, MN 2001.

Ostrowski J., Przygoda W., Seniorów duszpasterstwo, [w:] Leksykon teologii pastoralnej, red. R. Kamiński, Lublin 2006, s. 789-793.

Polska bibliografia homiletyczna 1945-2005, oprac. W. Przyczyna, L. Szewczyk, Kraków 2007. 
Przygoda W., Formacja apostolska ludzi w podeszłym wieku, „Perspectiva” 1 (2009), s. $170-184$.

Przygoda W., Wyzwania duszpasterskie wobec osób w podeszłym wieku, „Polonia Sacra" 38 (2015) nr 1, s. 71-94.

Sławiński H., Kontekstualne uwarunkowanie głoszenia katechez do młodzieży, „Pro Musica Sacra" 13 (2015), s. 53-69.

Sławiński H., Msza św. i homilia wedtug „Dyrektorium o Mszach św. z udziałem dzieci”. Aktualność dyrektorium w 40. rocznice powstania?, „Teologia i Człowiek” 28 (2014), s. 4, 97-115.

Staniek E., Z kaznodziejskiego warsztatu, Kraków 1997. 